\title{
SYNANTHROPIC RODENT RESERVOIRS OF Trypanosoma (Schizotrypanum) cruzi IN THE VALLEY OF CARACAS, VENEZUELA
}

\author{
Leidi HERRERA \& Servio URDANETA-MORALES
}

\begin{abstract}
SUMMARY
Direct blood examination and xenodiagnosis of 47 synanthropic rodents (Rattus rattus, $R$. norvegicus, Mus musculus) captured in the valley of Caracas, Venezuela, revealed trypanosomal infections in $12 \mathrm{R}$. rattus, 10 with $T$. lewisi and 2 with T. cruzi. Of the latter the course of parasitemia, the pleomorphism of the bloodstream trypomastigotes, tissue tropism in naturally and experimentally infected rats and mice, host mortality, morphology of fecal parasites in Rhodnius prolixus used for xenodiagnosis, and infectivity of the bug feces for NMRI mice, were all characteristic of Trypanosoma (Schizotrypanum) cruzi. One rat, with a patent parasitemia, had numerous nests of amastigotes in cardiac muscle and moderate parasitism of the smooth muscle of the duodenum and of skeletal muscle. Mice inoculated with fecal flagellates from the bugs had moderate tissue tropism in the same organs and also in the colon and pancreas. The possible role of $R$. rattus in the establishment of foci of Chagas' disease in Caracas is discussed.
\end{abstract}

KEYWORDS: Rattus rattus; Trypanosoma cruzi; Urban reservoir.

\section{INTRODUCTION}

The hemoflagellate Trypanosoma (Schizotrypanum) cruzi, the pathogen of American trypanosomiasis (Chagas' disease) is transmitted through fecal contamination by some 100 species of bloodsucking bugs (Hemiptera, Reduviidae, Triatominae); it infects more than 200 mammal species as reservoir hosts, particularly rodents and opossums ${ }^{2}$. The epidemiological significance of synanthropic rodents, especially Rattus spp. and Mus musculus is little known ${ }^{211}$.

In our current investigation of reservoir hosts of $T$. cruzi in the valley of Caracas $^{6}$, we have found infected $R$. rattus. The present paper describes infectivity, virulence, and tissue tropism of isolates of $T$. cruzi from these animals.

\section{MATERIALS AND METHODS}

"Tomahawk" and "Sherman" live traps, baited with fruits and/or sardines were placed within or near human dwellings in Colinas de Bello Monte, and occasionally in Caricuao, El Cafetal, Las Acacias, Los Chorros, San Roman, and Parque del Este, representative areas of the valley of Caracas ${ }^{13}$.

Fresh tail blood from the captured animals was examined at $400 \mathrm{X}$ and in Giemsa-stained smears at 400 and $1000 \mathrm{X}^{1,17}$. Blood flagellates, when found, were identified ${ }^{7} \cdot 16$ and counted $^{3}$. Each animal was xenodiagnosed by allowing $123^{\text {rd }}-$ stage laboratory-bred Rhodnius prolixus to engorge upon its blood. Feces of these bugs, spontaneously expelled or obtained by dissection, were examined diluted $1: 1$ in $0.85 \%$ saline for up to 45 days after engorgement. Flagellates in positive feces samples were counted by the technique of Brener ${ }^{3}$ and Giemsa stained smears were used for the study of morphology $y^{5}$.

Feces from positive bugs were inoculated i.p into 4 NMRI mice (av wt $15 \mathrm{~g}$ ) at a rate of 100 metacyclics/g body weight. The course of parasitemia was followed by examination of fresh blood as described above.

The possible presence of $T$. rangeli was checked by examining the hemolymph and salivary glands of xenodiagnostic bugs ${ }^{4}$.

Animals naturally infected with $T$. cruzi were sacrificed by anesthetic overdose with Ketaset (Ketamine $\mathrm{HCl}$, Fort Dodge Labs, USA). Samples of heart, skeletal muscle, liver, spleen, colon, duodenum, pancreas, kidney, urinary bladder, lungs, sternum, and skin were fixed in $10 \%$ formol, imbedded in paraffin, cut into $5 \mu$ sections, stained with hematoxylin and eosin, and examined at $1000 \mathrm{X}$. Mice infected by bug feces were examined by the same technique. Parasites detected in the viscera, in stained blood smears, and smears of bug feces were photographed with a Nikon Microflex HPX-35 on Ilford Pan F film. 
HERRERA, L. \& URDANETA-MORALES, S. - Synanthropic rodent reservoirs of Trypanosoma (Schizotrypanum) cruzi in the valley of Caracas, Venezuela. Rev. Inst. Med. trop. S. Paulo, 39(5): 279-282, 1997.

\section{RESULTS}

Thirty-seven adult and juvenile $R$. rattus, were captured in Colinas de Bello Monte, Los Chorros, El Cafetal, and Las Acacias. One $R$. norvegicus in Caricuao and 9 Mus musculus in Colinas de Bello Monte, Caricuao, San Roman, and Parque del Este were also captured. Of the $12 \mathrm{R}$. rattus captured in Colinas de Bello Monte, 10 showed infections with T. (Herpetosoma) lewisi on examination of stained blood smears. One of the remaining 2 rats had flagellates visible in fresh blood which had the typical pleomorphism of $T$. cruzi, with a predominance of stout forms (Fig. 1a) and a parasitemia of $20 \times 10^{3}$ flagellates $/ \mathrm{ml}$ blood. The other rat proved positive for $T$. cruzi by xenodiagnosis.

Stained smears of fecal material from the xenodiagnosis bugs had polymorphic forms resembling T. cruzi (Fig. 1b), and when inoculated into mice, infected all of them (strain CO 22). In the mice the prepatent period of the parasitemia averaged 13 days, with a low peak of parasitemia (av $45 \times 10^{3}$ trypomastigotes $/ \mathrm{ml}$ blood) on day 21 post-inoculation, at which time the mice were dying.

None of the experimental bugs had flagellates in the hemolymph or salivary glands, thus discarding the possibility of T. rangeli infection.

Tissue sections from the rat with patent parasitemia (strain CO 84) showed numerous pseudocysts (Fig. 2) with intracellular amastigotes in the heart and moderate parasitism of the smooth muscle of the duodenum and of skeletal muscle. All mice inoculated with bug fecal material (strain $\mathrm{CO} 22$ ) showed a moderate pattern of tissue tropism in the same organs and also in the colon and pancreas.

\section{DISCUSSION}

Natural T. cruzi infections in synanthropic rodents $(R$. rattus, $R$. norvegicus, $M$. musculus) have been reported from Texas (USA) to southern Brazil ${ }^{2}$. $R$. rattus is widely distributed, living in sylvatic ecotopes and in human shelters, where they may be abundant and have $T$. cruzi infection rates of up to $30 \%{ }^{15}$.

This intimate contact with humans has led them to be considered as important reservoir hosts in Venezuela, Colombia, Brazil, Peru, Panama, Costa Rica, and Trinidad', 9, 12, 19.

Experimental infections in laboratory animals with strains isolated from reservoir hosts are nearly always light, of long duration, chronic, and not lethal. Parasitemias are subpatent, detecTABLE only by xenodiagnosis and/or blood culture. Tissue parasitism is light or absent ${ }^{6}$. Our isolates from $R$. rattus behaved differently. All mice inoculated with fecal material from bugs used for xenodiagnosis (strain CO 22) showed low parasitemia and tissue parasitism that was not correlated with the death of the animals. They showed erection of the hair, low level of movement, intense urination, and limb paralysis before death, symptoms of a severe T. cruzi infection. LAINSON et al. $(1979)^{8}$ have reported lethal experimental infections in mice by isolates of $T$. cruzi from sylvatic or peridomestic mammals. In these there were abundant pseudocysts in the tissues, but very few bloodstream trypomastigotes.
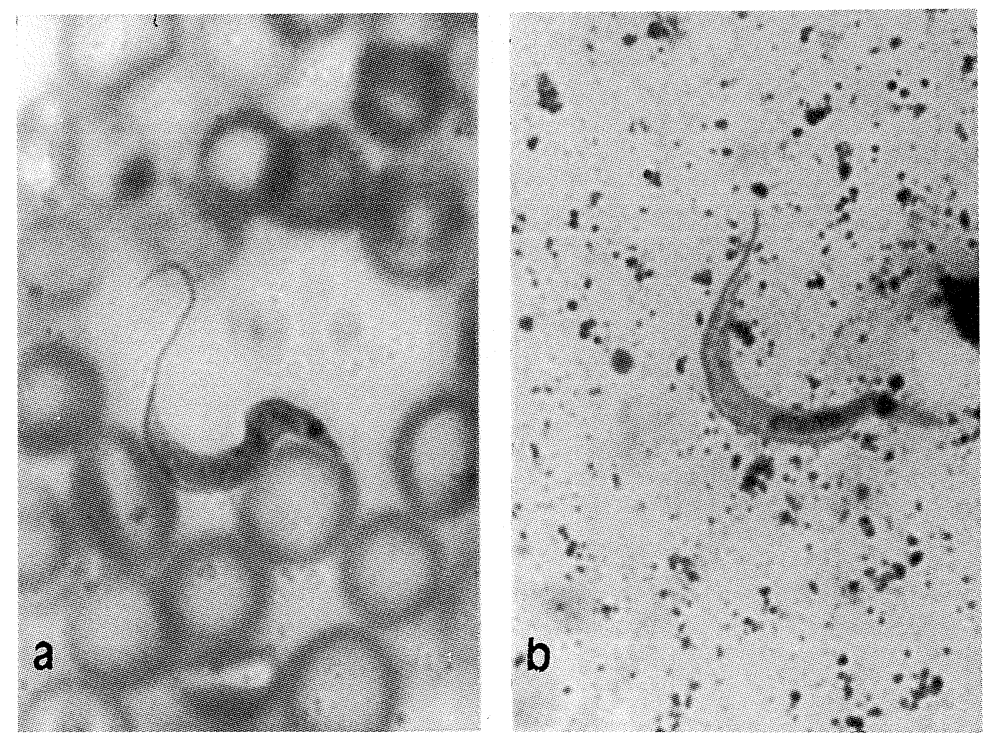

Fig. 1 - Flagellate stages of Trypanosoma cruzi:

a) Stout bloodstream trypomastigote from naturally infected Rattus rattus. (Giemsa, $1400 \mathrm{X}$ )

b) Metacyclic trypomastigote from feces of Rhodnius prolixus used for xenodiagnosis of naturally infected Rattus rattus. (Giemsa, $1400 \mathrm{X}$ ) 

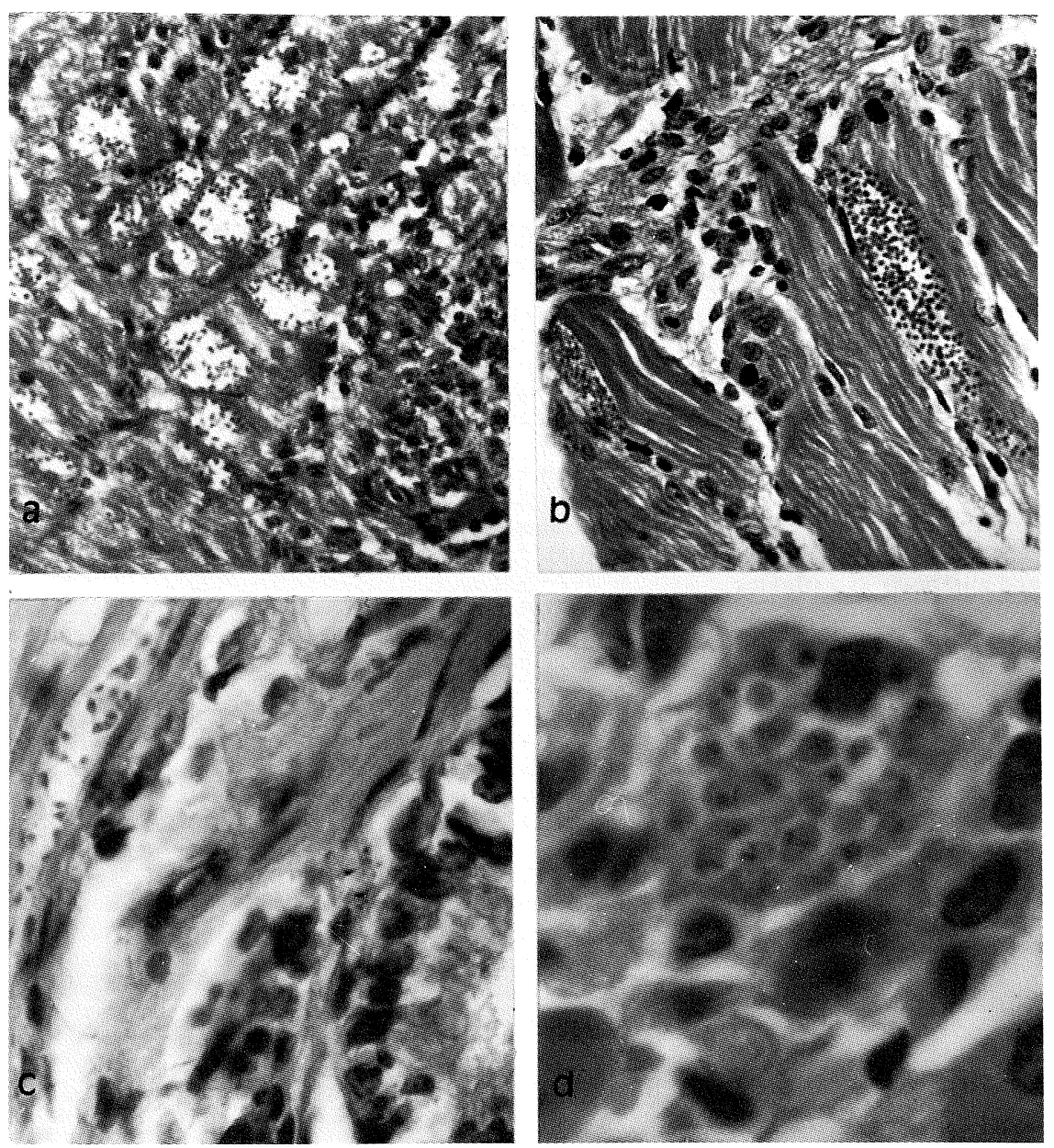

Fig. 2 - Histological sections showing pseudocysts of Trypanosoma cruzi with amastigotes in: a) Cardiac tissue of naturally infected Rattus rattus (strain CO 84 , Hematoxylin-eosin, $560 \mathrm{X}$ ) b) Skeletal muscle of naturally infected Rattus rattus (strain CO 84, Hematoxylin-eosin, $560 \mathrm{X}$ )

c) Smooth muscle fiber from colon of experimentally infected mouse (strain CO 22, Hematoxylin-eosin, $960 \mathrm{X}$ )

d) Acinar cell of pancreas of experimentally infected mouse (strain CO 22, Hematoxylin-eosin, $1400 \mathrm{X}$ )

Natural infections in $R$. rattus and $R$. norvegicus have been generally studied in sylvatic animals ${ }^{2,10,13}$ or from rural areas $^{2,10.18}$; few studies have been made on urban animals ${ }^{9,11}$.

Thirteen species of rodents have been incriminated in Venezuela as reservoir hosts for $T$. cruzi $i^{15}$, of which $R$. rattus, $R$. norvegicus, and Mus musculus live in close contact with humans, thus being important links in the transmission of $T$. cruzi to man and domestic animals.

The few studies of tissue parasitism in experimental animals by isolates of $T$. cruzi from $R$. rattus have shown invasion of heart and brain ${ }^{18}$; our studies have demonstrated cardio- and myotropism. As far as we know, the tissue tropism in naturally infected synanthropic rodents has not been investigated; we have observed many pseudocysts in cardiac muscle and in the smooth muscle of the duodenum, and moderate invasion of skeletal muscle in a naturally infected rat.

Our findings of natural $T$. cruzi infections in urban areas of the valley of Caracas, in the blood of opossums ${ }^{6}$ and of rats indicate that natural foci of Chagas' disease exist, and, while humans are not in direct contact with them, there is nevertheless a potencial epidemiological threat ${ }^{7}$. Infected reservoirs and vectors are present $t^{6.14}$ in the midst of a large human population of marginal sanitation.

Among the triatome vector - reservoir host complexes, the bug Panstrongylus geniculatus has been linked with opossums and armadillos ${ }^{2}$. This hematophagous insect is the only known 
HERRERA, L. \& URDANETA-MORALES, S. - Synanthropic rodent reservoirs of Trypanosoma (Schizotrypanum) cruzi in the valley of Caracas, Venezuela. Rev. Inst. Med. trop. S. Paulo, 39(5): 279-282, 1997.

vector in the valley of Caracas ${ }^{13}$, so that it presumably also feeds on rodents, particularly $R$. rattus.

\section{RESUMO}

\section{Reservatórios de roedores sinantrópicos de Trypanosoma (Schizotrypanum) cruzi no Vale de Caracas, Venezuela}

Exame direto de sangue e xenodiagnóstico de 47 roedores sinantrópicos (Rattus rattus, $R$. norvegicus, Mus musculus) capturados no Vale de Caracas, Venezuela, revelaram infecção por tripanosoma em $12 \mathrm{R}$. rattus, $10 \mathrm{com} \mathrm{T}$. lewisi e $2 \mathrm{com} T$. cruzi. Dos últimos o curso de parasitemia, o pleomorfismo dos tripomastigotas na corrente sangüínea, tropismo tissular em ratos e camundongos natural e experimentalmente infectados, mortalidade dos hospedeiros, morfologia dos parasitas fecais em Rhodnius prolixus usados para xenodiagnóstico e infectividade das fezes do "barbeiro" para camundongos NMRI, foram todos característicos de Trypanosoma (Schizotrypanum) cruzi. Um rato com parasitemia patente, tinha numerosos ninhos de amastigotas no músculo cardíaco e parasitismo moderado do músculo liso do duodeno e do músculo esquelético. Camundongos inoculados com flagelados fecais de "barbeiros" tinham tropismo tissular moderado nos mesmos órgãos e também no cólon e pâncreas. $\mathrm{O}$ possível papel do $R$. rattus no estabelecimento de focos de doença de Chagas em Caracas é discutido.

\section{ACKNOWLEDGEMENTS}

The authors wish to thank Mr. Ian McLure for technical assistance and aid in preparing the manuscript, and Mrs. Estefania Flores for preparing the histological sections.

This study was funded by Grant S1-2444 of the Consejo Nacional de Investigaciones Cientificas (CONICIT).

\section{REFERENCES}

1. BARRETTO, M.P. - Tripanosomas semelhantes ao Trypanosoma cruzi em animais silvestres e sua identificação com o agente etiológico da Doença de Chagas. Rev. Inst. Med. trop. S. Paulo, 7: 305-315, 1965.

2. BARRETTO, M. P. - Epidemiologia. In: BRENER, Z. \& ANDRADE, Z., ed. Trypanosoma cruzi e Doença de Chagas. Rio de Janeiro, Guanabara Koogan, 1979. p. $89-151$.

3. BRENER, Z. - Therapeutic activity and criterion of cure of mice experimentally infected with Trypanosoma cruzi. Rev. Inst. Med. trop. S. Paulo, 4: 389-396, 1962.

4. D'ALESSANDRO, A. \& SARAVIA, N. G. - Trypanosoma rangeli. In: KRIER, J. \& BAKER, J., ed. Parasitic protozoa. New York, Academic Press, 1992. v. 2, p. 1-54.

5. GARCIA, E. \& AZAMBUJA, P. - Development and interactions of Trypanosoma cruzi within the insect vector. Parasit. today, 7: 240-244, 1991.
6. HERRERA, L. \& URDANETA-MORALES, S. - Didelphis marsupialis: a primary reservoir of Trypanosoma cruzi in urban areas of Caracas, Venezuela. Ann. trop. Med. Parasit., 86: 607-612, 1992.

7. HOARE, C. A. - The trypanosomes of mammals. Oxford, Blackwell, 1972.

8. LAINSON, R.; SHAW, J.; PRAIHA, H.; MILES, M. \& DRAPER, C. - Chagas' Disease in the Amazon Basin. I. Trypanosoma cruzi infections in sylvatic mammals, triatomine bugs, and man in the State of Para, North Brazil. Trans. roy. Soc. trop. Med. Hyg., 73: 193-204, 1979.

9. MADARIAGA, R.; AYAONI, R. \& CORDOVA, E. - Infección natural de Rattus rattus y Mus musculus por Trypanosoma cruzi en la localidad de Caraveli, Arequipa, Peru. In:CONGRESO LATINOAMERICANO DE PARASITOLOGIA, 11., Lima, Peru, 1993.

10. MILES, M. - Distribution and importance of Triatominae as vectors of $T$. cruzi. In: New approaches in American trypanosomiasis research. Washington, PAHO, 1976. p. 48-53. (Scient. Publ. no. 318).

11. MINTER, D. M. - Effects on transmission to man of the presence of domestic animals in infested households. In: New approaches in American trypanosomiasis research. Washington, PAHO, 1976. p. 330-337 (Scient. Publ. no. 318).

12. PIFANO, F. - La dinámica epidemiológica de la Enfermedad de Chagas en el valle de Los Naranjos, Estado Carabobo. I. Contribución al estudio de los focos naturales silvestres del Schizotrypanum cruzi. Arch. venez. Med. trop. Parasit. med., 5: 3-29, 1973.

13. PIFANO, F. - El potencial enzoótico del complejo Schizotrypanum cruzi Didelphis marsupialis - Panstrongylus geniculatus y sus incursiones a la vivienda humana del Valle de Caracas, Venezuela. Bol. Acad. Cienc. Fis. Nat. Mat. (Caracas), 46: 9-37, 1986

14. SAMPSON-WARD, L. \& URDANETA-MORALES, S. - Urban Trypanosoma cruzi: biological characterization of isolates from Panstrongylus geniculatus. Ann. Soc. belge Med. trop., 68: 95-106, 1988.

15. TONN, R.; TELFORD, S.; CEDILLOS, R.; GONZALEZ, J. \& OTERO, N. Infección por tripanosomas en mamíferos silvestres de Venezuela. Bol. Direcc. Malar., 22: 23-33, 1982.

16. URDANETA-MORALES, S. - Pleomorphism in trypomastigotes of Trypanosoma cruzi from blood and cell culture. Tropenmed. Parasit., 34: 225-228, 1983.

17. WORLD HEALTH ORGANIZATION - Report of a meeting on the feasibility of analytical studies on Chagas' disease: guidelines for a standard protocol. Geneva, 1986

18. ZELEDON, R. \& PONCE, C. - Neurotropism in Costa Rican strains of Trypanosoma cruzi. J. Parasit., 58: 180-181, 1972

19. ZELEDON, R.; SOLANO, G.; BURSTIN, L. \& SCHWARZWALDER, J. Epidemiological patterns of Chagas' disease in an endemic area of Costa Rica. Amer. J. trop. Med. Hyg., 24: 214-225, 1975.

Recebido para publicação em 24/01/1997 Aceito para publicação em 02/10/1997 